\title{
Expression of Aquaporin 1 and 5 and Their Regulation by Ovarian Hormones, Arachidonic Acid, Forskolin and cAMP During Implantation in Pigs
}

\author{
A. SKOWRONSKA ${ }^{1}$, P. MLOTKOWSKA ${ }^{2}$, M. MAJEWSKI ${ }^{1}$, S. NIELSEN $^{3}$, \\ M. T. SKOWRONSKI ${ }^{2,4}$
}

${ }^{1}$ Department of Human Physiology, Faculty of Medical Sciences, University of Warmia and Mazury in Olsztyn, Olsztyn, Poland, ${ }^{2}$ Department of Animal Physiology, Faculty of Biology and Biotechnology, University of Warmia and Mazury in Olsztyn, Olsztyn, Poland, ${ }^{3}$ Department of Health Science and Technology, Faculty of Medicine, Aalborg University, Aalborg, Denmark, ${ }^{4}$ Institute of Veterinary, Poznań University of Life Sciences, Poznań, Poland

Received June 9, 2015

Accepted September 18, 2015

On-line March 15, 2016

\begin{abstract}
Summary
Aquaporin proteins (AQPs) are a family of channels expressed in numerous mammalian tissues, where they play a fundamental role in regulating water transport across cell membranes. Based on reports that AQPs are present in the reproductive system and participate in reproductive processes, our aim was to investigate the effect of progesterone $\left(P_{4}\right)$, estradiol $\left(E_{2}\right)$, oxytocin (OT), arachidonic acid (AA), forskolin (FSK) and cyclic adenosine monophosphate (CAMP) on AQP1 and AQP5 expression at mRNA and protein levels in porcine uterine explants from Days 14-16 of gestation in order to determine if they play a role in implantation period in pigs. Quantitative real time PCR and Western-blot analysis revealed that the uterine explants treated with FSK and CAMP produce delayed, but long-term effects on AQP1 abundance $(24 \mathrm{~h})$ while AQP5 had a rapid and sustained response to FSK and CAMP in protein content ( 3 and $24 \mathrm{~h}$ ). $\mathrm{AA}$ increases gene and protein content of AQP1 after longer exposition whereas AQP5 increases after $3 \mathrm{~h}$ only at the protein level. Both AQPs potentially remains under control of steroid hormones. OT has been shown to increase $A Q P 1$, and decrease $A Q P 5$ mRNA, without visible changes in protein content. $\mathrm{P}_{4}, \mathrm{E}_{2}$, $A A, F S K$ and cAMP caused the appearance of AQP5 expression in the basolateral plasma membrane of the epithelial cells. The staining represents most likely AQP5 functioning mechanism for both absorption and reabsorption across the glandular epithelium.
\end{abstract}

\section{Key words}

Aquaporins • Uterus • Implantation • Pig

\section{Corresponding author}

A. Skowronska, University of Warmia and Mazury in Olsztyn, Department of Human Physiology, Warszawska 30, 10-082 Olsztyn, Poland. Fax: +48 89 5245307. E-mail: agnieszka.skowronska@uwm.edu.pl

\section{Introduction}

The uterine endometrium undergoes morphological and physiological changes to a state supporting the implantation. Dramatic reduction in the intrauterine fluid takes place at the time of embryonic implantation (Zhang et al. 2012) as well as glandular secretions and fluid shifts across endothelial and epithelial compartments (Liu et al. 2014). Water homeostasis during fetal development is of crucial physiological importance throughout pregnancy. The presence of aquaporins suggests that water moves across the cell, not only through membrane lipid bilayer but also through water channels proteins (Agre et al. 2002). The aquaporins (AQPs) are family of small (25-34 kDa), hydrophobic, integral membrane proteins that facilitate the rapid transcellular movement of water and small neutral solutes in response to osmotic/hydrostatic 
pressure gradients. Accumulating evidence indicates that these proteins were found to be involved in embryo and uterine fluid homeostasis during pregnancy (Huang et al. 2006, Kobayashi and Yasui 2010, Sha et al. 2011, Zhu et al. 2015). The presence of AQP1, 4 and 5 was found in the mouse uterus on Day 1-8 of pregnancy (Richard et al. 2003), while $A Q P 1,3,4,5,7,8,9$ and 11 mRNA expression was observed in the human chronic villi between 10th and 14th weeks of gestation (Escobar et al. 2012). It has been shown that increased expression of AQP5 occurs at the time of the embryo implantation in the rat uterus (Lindsay and Murphy 2007). Further, multiple aquaporins are expressed in the early stage human embryos and AQP3 and AQP7 may play a role in pre-implantation mouse embryo development (Xiong et al. 2013). Implantation of the developing embryo in the uterus is regulated by multiple effectors, such as steroid hormones, growth factors, cytokines and cyclooxygenasederived prostaglandins (Bazer et al. 2009, Geisert et al. 2012). Unlike human and mouse, the pig has a noninvasive implantation (Bazer 1975, Kaufmann and Burton 1999) and release of embryonic estrogen serves as the signal for maternal recognition of pregnancy (Keys and King 1990, Jaeger et al. 2001). Furthermore, estrogen also regulates the expression of a variety of genes in the uterus that support implantation and conceptus development (Johnson et al. 2009). It has been found that, besides estrogens, the endometrium and trophoblast synthesize elevated amounts of prostaglandin $\mathrm{E}_{2}\left(\mathrm{PGE}_{2}\right)$ (Akinlosotu et al. 1986, Christenson et al. 1994). There is also evidence that prostaglandin $\mathrm{F}_{2 \alpha} \quad\left(\mathrm{PGF}_{2 \alpha}\right)$ and prostaglandin $\mathrm{E}_{2}$ are required for conceptus development and implantation (Kraeling et al. 1985, Ziecik et al. 2011). Some studies also revealed that ovarian steroid hormones $\left(\mathrm{E}_{2}\right.$ and $\left.\mathrm{P}_{4}\right)$, arginine vasopressin, forskolin, cAMP, relaxin and insulin may be involved in the regulation of AQPs expression in the reproductive system, for a review see Hua et al. (2013). It has also been postulated that pig endometrium secretes oxytocin (Trout et al. 1995), possesses its receptors (Whiteaker et al. 1994) and regulates $\mathrm{PGF}_{2 \alpha}$ secretion (Uzumcu et al. 1998).

In previous studies (Skowronski et al. 2009, Skowronski 2010), we provided an anatomical basis for AQP 1, 5 and 9 expression in the porcine uterus during different stages of the estrous cycle and pregnancy. AQP1 expression was present in the endothelial cells of the blood vessels, AQP5 in the cells of myometrium and the luminal and glandular epithelium. However, the AQPs gene expression and AQPs regulation controlling uterine fluid homeostasis has not been examined in porcine uterine tissue. Very recently, an in vitro study of corresponding cyclic uterus gene/protein expression has been performed by Skowronska et al. (2015). There is little information available about water transport mechanism during implantation in the pig. Based on these data, we have designed an in vitro experiment to elucidate whether the steroid hormones, progesterone $\left(\mathrm{P}_{4}\right)$ and estradiol $\left(\mathrm{E}_{2}\right)$, and other factors: oxytocin (OT), arachidonic acid (AA; substrate for prostaglandins synthesis) as well as forskolin (FSK; adenylate cyclase activator) and cAMP (second messenger, cyclic adenosine monophosphate) may impact AQPs expression during implantation (Days 14-16 of gestation). Consequently, the primary aim of this study was to: (i) examine the changes in AQP1 and AQP5 at mRNA and protein levels in porcine uterine explants in the presence of $\mathrm{P}_{4}, \mathrm{E}_{2}, \mathrm{OT}, \mathrm{AA}, \mathrm{FSK}$ and cAMP; (ii) determine the effect of exposure time to the experimental factors on AQP1 and 5 expression in uterine explants; (iii) examine the localization of AQP1 and 5 in uterine explants after a certain incubation period with examined factors.

\section{Materials and Methods}

\section{Animals and collection of uterine tissue}

The experiment was performed in accordance with Animal Ethics Committee, University of Warmia and Mazury in Olsztyn, Poland (AEC approval No. $66 / 2010 / D T N)$ and conducted at the University of Warmia and Mazury. Gilts (Large White $\times$ Polish Landrace) were observed daily for estrus behavior, and they were used in the study during their third consecutive normal estrous cycle. They were naturally bred on the second day of estrus. The animals were slaughtered $(n=5)$ at a local abattoir, and tissue samples were recovered from mature cross-bred gilts on Day 14-16 of pregnancy which corresponds to the period of implantation in pigs. Pregnancy was confirmed by the presence of embryos after flushing uterine horns with $20 \mathrm{ml}$ of sterile saline. The uteri were placed immediately in ice-cold phosphatebuffered saline (PBS), supplemented with $100 \mathrm{IU} / \mathrm{ml}$ penicillin (Polfa, Poland) and $100 \mu \mathrm{g} / \mathrm{ml}$ streptomycin (Polfa, Poland) and transported to the laboratory on ice within $1 \mathrm{~h}$ for in vitro tissue culture. 
Table 1. Primer pairs used in the study.

\begin{tabular}{ll}
\hline PCR product & Sequence \\
\hline$A Q P 1$ & Forward: 5'-CCAGCGAGTTCAAGAAGAAG-3' \\
& Reverse: 5'-GCGACACCTTCACGTTATC-3' \\
AQP5 & Forward: 5'-CTATGAGTCCGAGGAGGATT-3' \\
& Reverse: 5'-GCTTCGCTGTCATCTGTT-3' \\
$18 S r R N A$ & Forward: 5'-GGCTACCACATCCAAGGAAG-3' \\
& Reverse: 5'-TCCAATGGATCCTCGCGGAA-3' \\
GADPH & Forward: 5'-GACCTCCACTACATGGTCTA-3' \\
& Reverse: 5'-AAGATGGTGATGGCCTTTC-3' \\
\hline
\end{tabular}

\section{Uterine explants culture}

Sections of the middle part of uterine horn collected from pigs were opened longitudinally on the mesometrial surface. Uteri were washed three times in sterile PBS then carefully cut into small slices $(400 \mathrm{mg}$ weight) and then washed three times in medium M199 (Sigma, USA). Individual uterine slices were placed in culture vials containing $2 \mathrm{ml}$ Medium 199 supplemented with $0.1 \%$ BSA (Sigma), $20 \mu$ g nystatin (Sigma) and $20 \mu \mathrm{g}$ gentamicin (Krka, Novo Mesto, Slovenia) and then incubated in a shaking water bath at $37{ }^{\circ} \mathrm{C}$ in a humidified atmosphere of $95 \% \mathrm{O}_{2}$ and $5 \% \mathrm{CO}_{2}$ for $18 \mathrm{~h}$ (Franczak et al. 2006). After preincubation, the culture medium was replaced with fresh medium, and the explants were treated with vehicle (control) or $\mathrm{P}_{4}$ $\left(10^{-5} \mathrm{M}\right.$; Sigma), $\mathrm{E}_{2}\left(10^{-9} \mathrm{M}\right.$; Sigma), OT $\left(10^{-7} \mathrm{M}\right.$; Sigma), AA $\left(10^{-5} \mathrm{M}\right.$; Sigma), FSK $(10 \mu \mathrm{g} / \mathrm{ml}$; Sigma $)$ and cpt-cAMP analog (200 $\mu$ M; Sigma) and incubated for an additional 3 or $24 \mathrm{~h}$. Concentrations for the treatments were previously determined (Yang et al. 2003, Franczak et al. 2006). All treatments were performed in triplicates in five independent experiments. Furthermore, uterine tissue explants were snap-frozen in liquid nitrogen (for RNA and protein extraction) and stored at $-80{ }^{\circ} \mathrm{C}$ until further use.

Total RNA isolation, cDNA synthesis and quantitative real-time PCR analysis

Total RNA was extracted, using the total RNA Prep Plus kit (A\&A Biotechnology, Poland) according to the manufacturer's protocol, from uterine explants collected after in vitro culture (Skowronska et al. 2015). Total RNA quality and quantity were determined with spectrophotometry (NanoDrop ND-1000, Thermo Scientific, Wilmington, DE, USA). Total RNA samples were transcribed to cDNA using an Enhanced Avian HS RT-PCR Kit it (Sigma) and a mix of dNTPs and random hexamers as primers. Real-Time PCR was performed in duplicate for each sample using a 7300 Real-Time PCR system and SYBR ${ }^{\circ}$ Green PCR Master Mix (Life Technologies, Grand Island, NY, USA). Real-Time PCR reaction included $12.5 \mu \mathrm{l}$ SYBR Green PCR master mix, $1 \mu \mathrm{M}$ forward and reverse primers each and reverse transcribed cDNA $(3.5 \mu \mathrm{l}$ of diluted RT product) supplemented with water to a volume of $25 \mu 1$. The conditions of the thermal cycling for each gene were: initial denaturation for $10 \mathrm{~min}$ at $95^{\circ} \mathrm{C}$, denaturation for $15 \mathrm{~s}$ at $95^{\circ} \mathrm{C}$, primer annealing for $1 \mathrm{~min}$ at $60^{\circ} \mathrm{C}$. Specific primers for $A Q P 1$ and $A Q P 5$ (Table 1) were designed with the Primer Express 3.0 software (Life Technologies) and their specificities were confirmed by comparison of their sequences with the sequence of $A Q P 1$ and $A Q P 5$ deposited in a database and calculation of the statistical significance of the match was performed using the Basic Local Alignment Search Tool (BLAST). For the specificity control, non-template controls and dissociation curve analysis of the amplified products were used for each amplification. The specificity of amplifications was further validated with electrophoresis of the putative amplicons in a $2 \%$ agarose gel and, after extraction from gel, automated sequencing using 3730xl DNA Analyzer (Life Technologies). Levels of gene expression were calculated using the $\Delta \Delta \mathrm{Ct}$ method and normalized using the geometrical means of reference genes expression levels, glyceraldehyde 3-phosphate dehydrogenase (GAPDH) and $18 S$ rRNA.

\section{SDS-PAGE and Western Blot analysis}

The tissues were placed in ice-cold dissection buffer ( $0.3 \mathrm{M}$ sucrose, $25 \mathrm{mM}$ imidazol, $1 \mathrm{mM}$ EDTA in 
$\mathrm{ddH}_{2} \mathrm{O}, \mathrm{pH}$ 7.2) containing $8.4 \mu \mathrm{M}$ leupeptin and $0.4 \mathrm{mM}$ pefabloc (Skowronski 2010). The tissue samples were homogenized using an ultra Turrax T8 homogeniser (IKA Labortechnik, Staufen, Germany) and centrifuged at $4000 \times \mathrm{g}$ for $15 \mathrm{~min}$ at $4{ }^{\circ} \mathrm{C}$. The supernatant was diluted in SDS buffer contained a final concentration of $62 \mathrm{mM}$ Tris (hydroxymethyl)aminomethane, 0.1 M sodium dodecyl sulphate (SDS), $8.7 \%$ glycerol, $0.09 \mathrm{mM}$ bromophenol blue and $0.04 \mathrm{M}$ dithiothreitol (DTT), pH 6.8. The protein samples were heated for $5 \mathrm{~min}$ at $90{ }^{\circ} \mathrm{C}$ and stored in refrigerator for further analysis. Total protein amounts were determined with spectrophotometry (NanoDrop ND-1000, Thermo Scientific, Wilmington, DE, USA). The samples warmed up to $37^{\circ} \mathrm{C}$ were loaded into $12.5 \%$ polyacrylamide gels and proteins were separated by electrophoresis. The proteins of studied gels were then electro-transferred onto nitrocellulose membranes (Hybond ECL RPN3032D, Amersham Pharmacia Biotech, Little Chalfont, UK) for $1 \mathrm{~h}$ at $100 \mathrm{~V}$. The membranes were blocked with $5 \%$ milk in PBS-T (80 mM Na $2 \mathrm{HPO}_{4}, 20 \mathrm{mM} \mathrm{NaH} \mathrm{PO}_{4}, 100 \mathrm{mM} \mathrm{NaCl}$, pH 7.5 and $0.1 \%$ vol/vol Tween 20) for $1 \mathrm{~h}$. After washing, the membranes were incubated overnight at $5{ }^{\circ} \mathrm{C}$ with anti-AQPs or $\beta$-actin antibodies. Thereafter, the membranes were washed and incubated with horseradish peroxidase-conjugated goat anti-rabbit IgG secondary antibody (P448, diluted 1:3000, Dako A/S, Glostrup, Denmark) in PBS-T for $1 \mathrm{~h}$. After washing with PBS-T, the sites of antibody-antigen reaction were visualized with an enhanced chemiluminescence (ECL) system (Amersham Pharmacia Biotech, Little Chalfont, UK) and exposure to photographic film (Hyperfilm ECL, RPN3103K, Amersham Pharmacia Biotech, Little Chalfont, UK). The results of Western blotting were quantified by densitometric scanning of immunoblots with GelScan for Windows ver. 1.45 software (Kucharczyk, Poland). Data were expressed as a ratio of AQP proteins relative to actin protein in OD units.

\section{Immunohistochemistry}

For preparation of paraffin-embedded tissue sections ( $4 \mu \mathrm{m}$ thickness), the tissues were dehydrated in ethanol followed by xylene and finally embedded in paraffin (Skowronski et al. 2007). The staining was carried out using indirect immunoperoxidase. The sections were dewaxed and rehydrated. For immunoperoxidase labeling, endogenous peroxidase was blocked by $0.5 \% \mathrm{H}_{2} \mathrm{O}_{2}$ in absolute methanol for $10 \mathrm{~min}$ at room temperature. To reveal antigens, the sections were submerged in $1 \mathrm{mM}$ Tris solution ( $\mathrm{pH}$ 9.0) supplemented with $0.5 \mathrm{mM}$ EGTA and heated in a microwave oven. After the treatment, the sections were left for $30 \mathrm{~min}$ in the buffer for cooling. Nonspecific binding of $\mathrm{IgG}$ was eliminated by incubating the sections in $50 \mathrm{mM} \mathrm{NH} \mathrm{NH}_{4}$ for $30 \mathrm{~min}$, followed by blocking in PBS supplemented with $1 \%$ BSA, $0.05 \%$ saponin and $0.2 \%$ gelatin. The sections were incubated overnight at $4{ }^{\circ} \mathrm{C}$ with primary antibodies (see below) diluted in PBS supplemented with $0.1 \%$ BSA and $0.3 \%$ Triton X-100. The sections were rinsed with PBS supplemented with $0.1 \%$ BSA, $0.05 \%$ saponin and $0.2 \%$ gelatin, and then incubated with horseradish peroxidase-conjugated secondary antibody (Dako A/S, Glostrup, Denmark). Labeling was visualized by $0.05 \%$ 3,3-diaminobenzidine tetrahydrochloride (DAB). The microscopy was carried out using an Olympus light microscope (BX51, Japan).

\section{Primary antibodies}

Antibodies to AQP1 and AQP5, used in Western blot analysis and immunocytochemistry, were previously characterized, respectively by Terris et al. (1996) and Nielsen et al. (1997). All polyclonal antibodies were affinity-purified (SulfoLink Kit, Pierce, Rockford, IL). The anti- $\beta$-actin antibody was used (cat. no. A2066; Sigma-Aldrich, St Louis, MO). In our previous study, we demonstrated that anti-AQP1 and anti-AQP5 antibodies preincubated with the immunizing peptide prevented labeling in the pig uterus (Skowronski 2010). In addition, immunoglobulins from non-immunized rabbit were used as a negative control (Fig. 5 c and Fig. 6 o-p).

\section{Statistical analysis}

All numerical data were analyzed by one-way ANOVA and least significant difference (LSD) post hoc test and reported as the means \pm S.E.M. from five separate experiments (pigs), each performed in triplicates. Statistical analyses were performed using the Statistica program (StatSoft Inc., Tulsa, USA). Values for $\mathrm{p}<0.05$ were considered statistically significant.

\section{Results}

Effects of $P_{4}, E_{2}, O T, A A, F S K$, and cAMP on AQP1 and AQP5 $\mathrm{mRNA}$ expression in uterine tissue explants

Using quantitative real time PCR, we have found the presence of the investigated AQP isoforms $A Q P 1$ and $A Q P 5$ mRNA in porcine uterine explants during the 
implantation period. The level of the $A Q P 1$ and $A Q P 5$ transcripts fluctuated in the tissue depending on the incubation time; 3-h and 24-h (Figs 1 and 2). In detail, in porcine uterine explants $A Q P 1$ mRNA expression decreased significantly $(\mathrm{p}<0.05)$ after 3 -h treatment with $\mathrm{E}_{2}$, oxytocin, $\mathrm{AA}$ and cAMP when compared to the respective control. However, a significant increase in $A Q P 1$ mRNA expression was seen after longer treatment (24-h) with oxytocin, AA, cAMP and FSK $(\mathrm{p}<0.05)$. In contrast, $\mathrm{P}_{4}$ did not affect the expression of $A Q P 1$ mRNA neither after short nor longer incubation (3-h and 24-h, respectively). The relative control abundance of $A Q P 1$ transcript harvested in the uterine tissue was approximately 3-fold higher than $A Q P 5$ after 3-h incubation (Fig. 1). Progesterone had no effect on $A Q P 5$ mRNA level in the uterine porcine explants after 3 or $24 \mathrm{~h}$ incubation. Treatment of uterine explants with $\mathrm{E}_{2}$, OT and AA resulted in decreased $A Q P 5$ expression after $3 \mathrm{~h}$, when compared to respective control values $(\mathrm{p}<0.05$, Fig. 2). The level of $A Q P 5$ mRNA of uterine explants remained markedly low after longer incubation $(24 \mathrm{~h})$ with OT. On the contrary, in vitro treatment of uterine explants with cAMP caused an increase in uterine $A Q P 5$ expression, but only after $24-\mathrm{h}$ ( $\mathrm{p}<0.05$, Fig. 2).

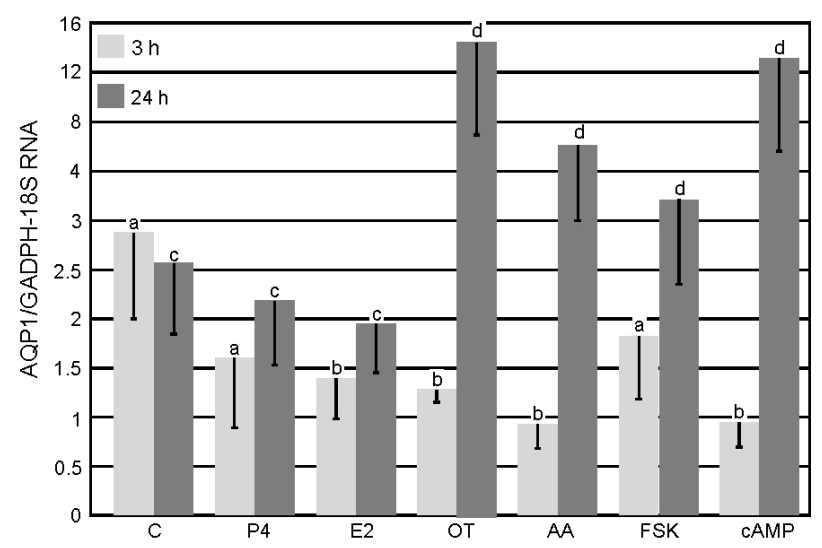

Fig. 1. $A Q P 1$ mRNA expression in porcine uterine explants determined by real-time PCR. The expression of $A Q P 1$ mRNA in the pig uterine tissue harvested on Days 14-16 $(n=5)$ of pregnancy after treatment with progesterone $\left(\mathrm{P}_{4} ; 10^{-5} \mathrm{M}\right)$, estradiol $\left(E_{2} ; 10^{-9} \mathrm{M}\right)$, oxytocin $\left(\mathrm{OT} ; 10^{-7} \mathrm{M}\right)$, arachidonic acid $\left(\mathrm{AA} ; 10^{-5} \mathrm{M}\right)$, forskolin (FSK; $10 \mu \mathrm{g} / \mathrm{ml}$ ), and cyclic-AMP (CAMP; $200 \mu \mathrm{M})$. The uterine explants $(\sim 400 \mathrm{mg})$ were pre-incubated $\left(18 \mathrm{~h} ; 37{ }^{\circ} \mathrm{C}, 95 \% \mathrm{O}_{2}+5 \% \mathrm{CO}_{2}\right.$ ) and then incubated without (C) or with the addition of experimental factors for 3 and $24 \mathrm{~h}$. The data are presented as the mean values \pm standard error of the mean relative to the mean ref. expression of GAPDH and 18 sRNA. Different letters $(\mathrm{a}, \mathrm{b}, \mathrm{c}, \mathrm{d})$ indicate significant differences $(p<0.05)$ between each treatment and respective control for 3-h $(a, b)$ or 24-h (c, d) incubations.

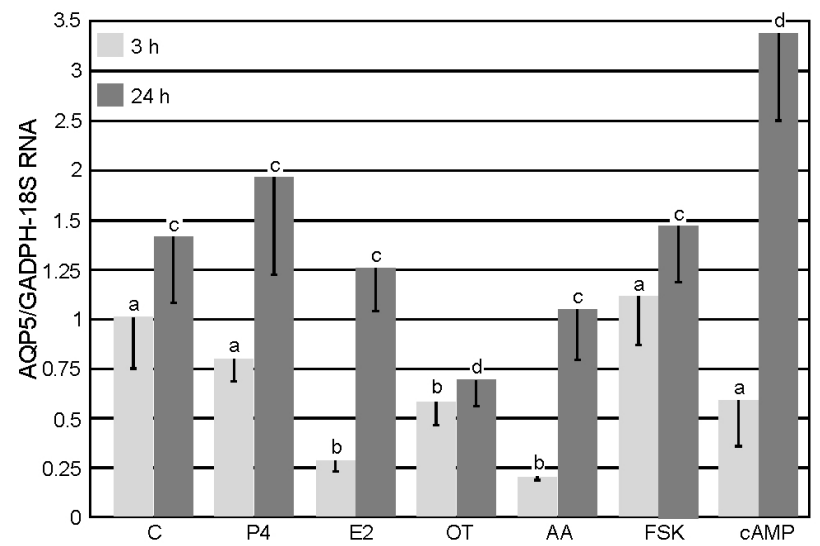

Fig. 2. $A Q P 5$ mRNA expression in porcine uterine explants determined by real-time PCR. The expression of $A Q P 5$ mRNA in the pig uterine tissue harvested on Days 14-16 $(n=5)$ of pregnancy after treatment with progesterone $\left(\mathrm{P}_{4} ; 10^{-5} \mathrm{M}\right)$, estradiol $\left(E_{2} ; 10^{-9} \mathrm{M}\right)$, oxytocin $\left(\mathrm{OT} ; 10^{-7} \mathrm{M}\right)$, arachidonic acid (AA; $10^{-5} \mathrm{M}$ ), forskolin (FSK; $10 \mu \mathrm{g} / \mathrm{ml}$ ), and cyclic-AMP (CAMP; $200 \mu \mathrm{M})$. The uterine explants $(\sim 400 \mathrm{mg}$ ) were pre-incubated $\left(18 \mathrm{~h} ; 37^{\circ} \mathrm{C}, 95 \% \mathrm{O}_{2}+5 \% \mathrm{CO}_{2}\right)$ and then incubated without (C) or with addition of experimental factors for 3 and 24 h. Data are presented as the mean values \pm standard error of the mean relative to the mean ref. expression of GAPDH and 18 SRNA. Different letters $(a, b, c, d)$ indicate significant differences $(p<0.05)$ between each treatment and respective control for 3-h $(\mathrm{a}, \mathrm{b})$ or 24-h (c, d) incubations.

Effects of $P_{4}, E_{2}, O T, A A, F S K$, and cAMP on $A Q P 1$ and $A Q P 5$ protein expression in uterine tissue explants

Figures 3 and 4 show Western blot analysis of $\mathrm{AQP} 1$ and 5 protein in uterine tissue explants during implantation. It was demonstrated that both aquaporins were expressed in porcine uterine tissue explants at both exposure times. A band of AQP1 protein product of the expected size $(29 \mathrm{kDa})$ was clearly detected in all studied tissues (Fig. 3). A stimulatory effect on AQP1 expression was observed after treatment of explants with $\mathrm{E}_{2}$ and $\mathrm{P}_{4}$ during 3-h and 24-h incubations, respectively ( 1.5-2.5 fold, $\mathrm{p}<0.05)$. In turn, AA, FSK and cAMP treatment for $3 \mathrm{~h}$ did not significantly affect AQP1 protein expression but after longer incubation $(24 \mathrm{~h})$ it stimulated its expression $(p<0.05)$. In contrast, OT did not affect the protein expression of AQP1. The effect of studied factors on the expression of AQP5 protein is presented in Figure 4. A band of $28 \mathrm{kDa}$ that represented AQP5 was detected. AQP5 protein expression in uterine explants representing implantation significantly increased after 3-h treatment with $\mathrm{P}_{4}, \mathrm{E}_{2}, \mathrm{AA}$, FSK and cAMP $(\mathrm{p}<0.05)$ and remained elevated after 24-h ( $<<0.05)$, except AA. Similar to AQP1, in the presence of OT, AQP5 protein content in uterine explants was not affected during either incubation times. Treatment with AA resulted in an elevation of AQP5 protein only after 3 -h incubation $(\mathrm{p}<0.05)$. 

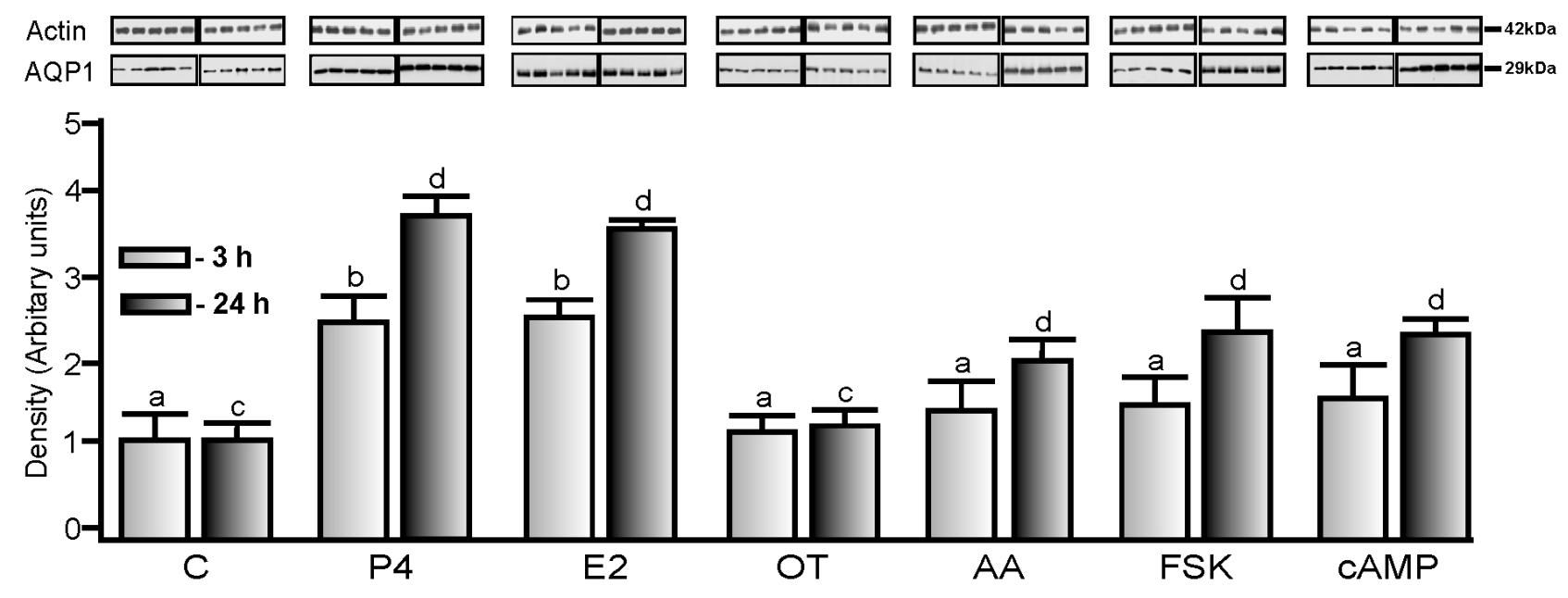

Fig. 3. Protein content of $A Q P 1$ in uterine explants. Semi-quantitative Western blot analysis of $A Q P 1$ in homogenates of the pig uterine explants from Days 14-16 of pregnancy (each lane represents a sample from 1 pig), after treatment with progesterone $\left(P_{4} ; 10^{-5} M\right)$, estradiol $\left(\mathrm{E}_{2} ; 10^{-9} \mathrm{M}\right)$, oxytocin (OT; $\left.10^{-7} \mathrm{M}\right)$, arachidonic acid $\left(\mathrm{AA} ; 10^{-5} \mathrm{M}\right)$, forskolin (FSK; $\left.10 \mu \mathrm{g} / \mathrm{ml}\right)$, and cyclic-AMP (CAMP; $\left.200 \mu \mathrm{M}\right)$. The uterine explants ( $400 \mathrm{mg}$ ) were pre-incubated $\left(18 \mathrm{~h} ; 37{ }^{\circ} \mathrm{C}, 95 \% \mathrm{O}_{2}+5 \% \mathrm{CO}_{2}\right.$ ) and then incubated without (C) or with addition of experimental factors for 3 and $24 \mathrm{~h}$. Densitometric analysis of AQP1 protein levels was performed and normalized against $\beta$-actin $(42 \mathrm{kDa})$ and different letters $(a, b, c, d)$ indicate significant differences $(p<0.05)$ between each treatment and respective control for 3-h $(a, b)$ or 24-h (c, d) incubations.

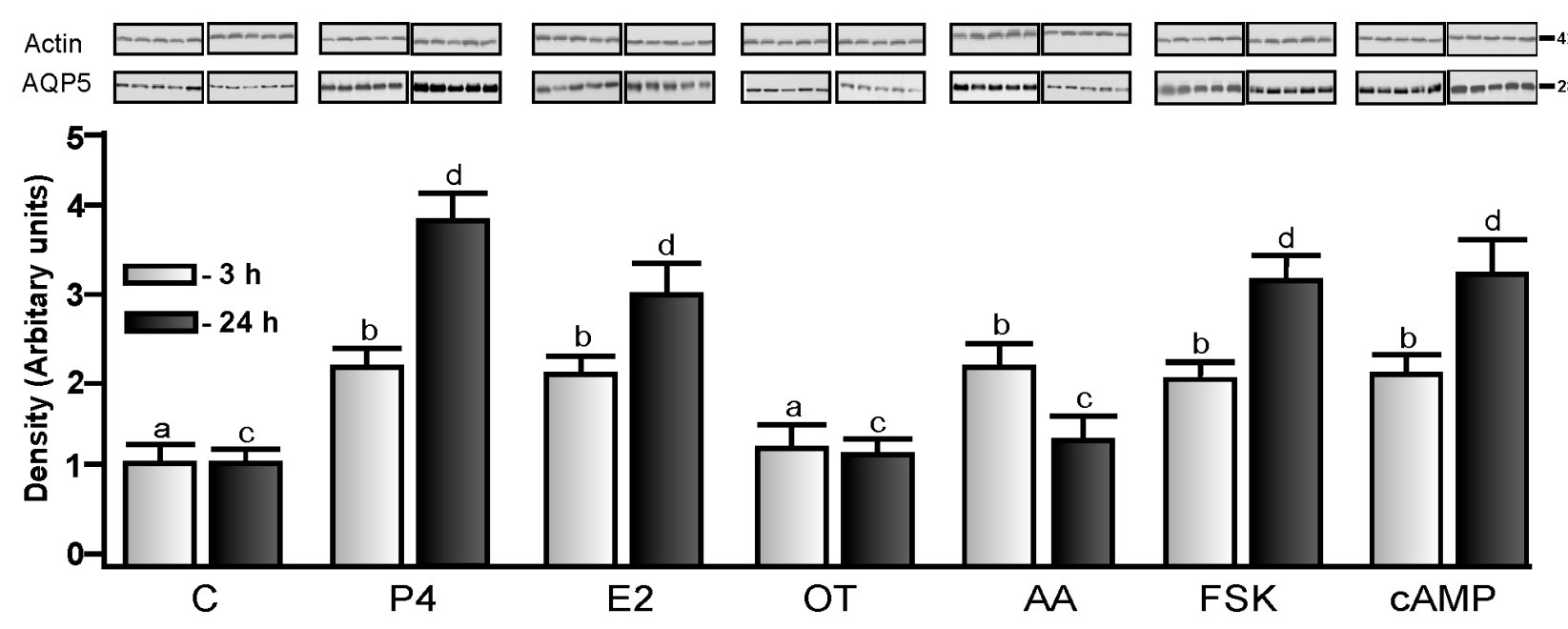

Fig. 4. Protein content of $A Q P 5$ in uterine explants. Semi-quantitative Western blot analysis of $A Q P 5$ in homogenates of the pig uterine explants from Days 14-16 of pregnancy (each lane represents a sample from $1 \mathrm{pig}$ ), after treatment with progesterone $\left(\mathrm{P}_{4} ; 10^{-5} \mathrm{M}\right)$, estradiol $\left(E_{2} ; 10^{-9} \mathrm{M}\right)$, oxytocin $\left(\mathrm{OT} ; 10^{-7} \mathrm{M}\right)$, arachidonic acid $\left(\mathrm{AA} ; 10^{-5} \mathrm{M}\right)$, forskolin (FSK; $\left.10 \mu \mathrm{g} / \mathrm{ml}\right)$, and cyclic-AMP (CAMP; $\left.200 \mu \mathrm{M}\right)$. The uterine explants ( $400 \mathrm{mg}$ ) were pre-incubated $\left(18 \mathrm{~h} ; 37^{\circ} \mathrm{C}, 95 \% \mathrm{O}_{2}+5 \% \mathrm{CO}_{2}\right.$ ) and then incubated without (C) or with addition of experimental factors for 3 and $24 \mathrm{~h}$. Densitometric analysis of AQP5 was performed and normalized against $\beta$-actin ( $42 \mathrm{kDa})$ and different letters $(a, b, c, d)$ indicate significant differences $(p<0.05)$ between each treatment and respective control for $3-h(a, b)$ or 24-h (c, d) incubations.

Immunohistochemical localization of $A Q P 1$ and $A Q P 5$ in uterine tissue explants during the implantation period

In the tissue sections of the pig uterus, control and after 3-h exposure to $\mathrm{P}_{4}$, immunoperoxidase labeling for AQP1 was associated with uterine endothelial cells during the implantation period (Fig. 5 a and b). Both the apical and basal plasma membranes exhibited stable AQP1 labeling (arrows) without changes in localization within the cells. In turn, in sections of the porcine uterus treated with control and chosen factors, immunoperoxidase labeling for AQP5 was associated with uterine epithelial cells (Fig. 6 a-j) and smooth muscle cells (Fig. 6 k-n). Following 3-h and 24-h treatments of the tissue with $\mathrm{P}_{4}, \mathrm{E}_{2}$, FSK and cAMP as well as 3-h treatment with AA during the implantation period, a prominent AQP5 labeling was seen in both the 
apical and basolateral plasma membranes of the epithelial cells (Fig. 6 b-j). In the smooth muscle cells, in contrast to the epithelial cells, changes in AQP5 localization within the cell membranes were not observed in control (Fig. $6 \mathrm{k}-\mathrm{l}$ ) and response to 3 -h treatment with $\mathrm{P}_{4}$ (Fig. $6 \mathrm{~m}$-n).

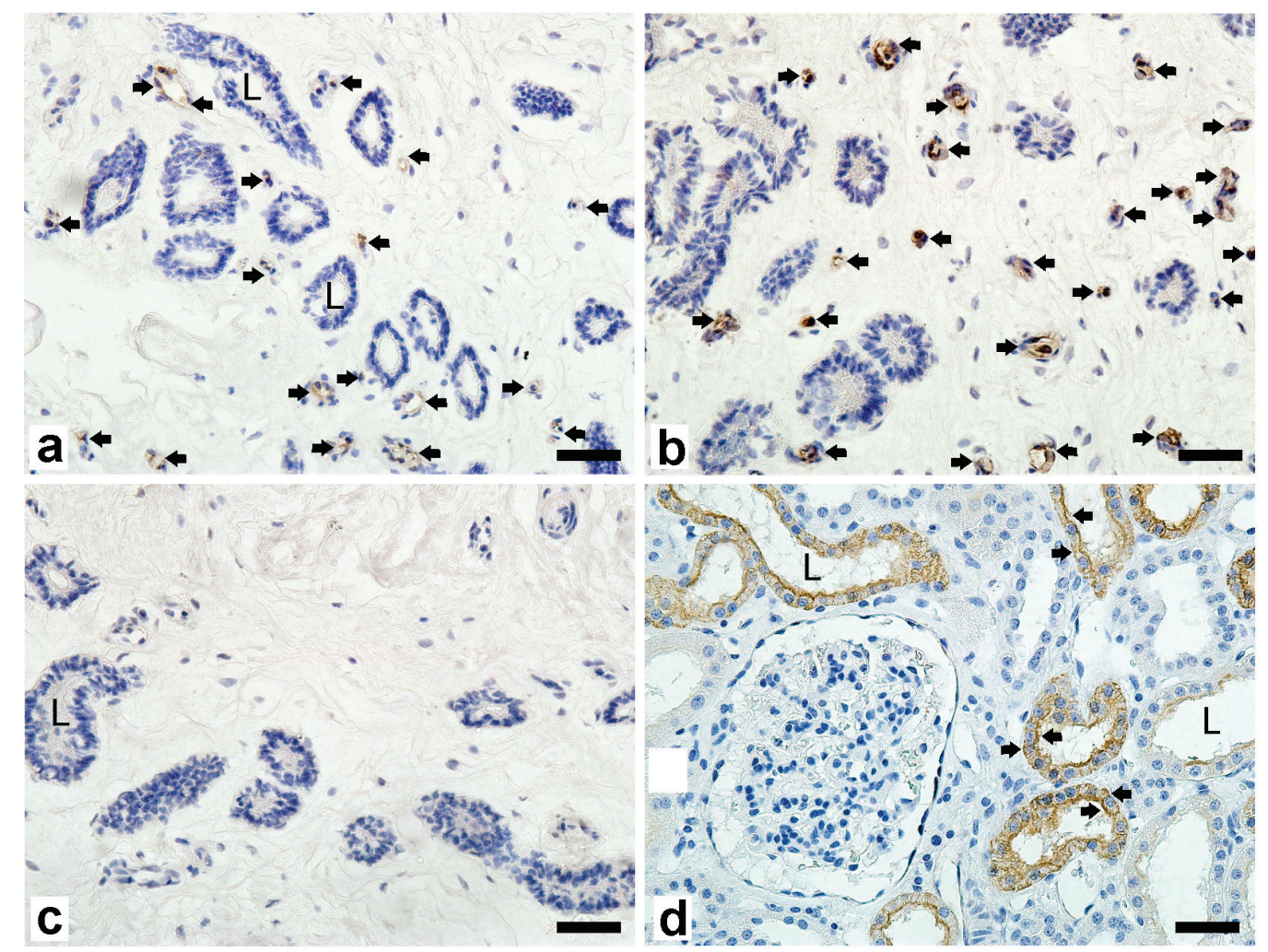

Fig. 5. Immunohistochemical localization of $A Q P 1$ in uterine tissue explants. Immunoperoxidase staining of $A Q P 1$ in paraffin-embedded sections of the uterine explants from pigs on Days 14-16 of pregnancy. Anti-AQP1 antibody labels endothelial cells of the uterine explants (arrows). Both apical and basal plasma membranes exhibited stable AQP1 labeling in control (a) and $\mathrm{P}_{4}$-treated uterine explants for 3-h (b). Negative control for AQP1 was performed by using non-immune IgG, and no specific immunostaining was observed (c). Immunoperoxidase labeling of AQP1 in the pig kidney cortex (d/ positive control). The labeling is seen in both of the apical and basolateral plasma membrane in proximal tubule cells. $\mathrm{L}-$ lumen. Bar $=50 \mu \mathrm{m}$

\section{Discussion}

In the present study, we have shown in vitro the effect of $\mathrm{P}_{4}$ and $\mathrm{E}_{2}$, oxytocin, AA, FSK and cAMP on AQP1 and AQP5 expression at mRNA and protein levels in porcine uterine explants from the implantation period. Implantation in pigs is characterized by trophoectoderm attachment of the blastocyst to the endometrial luminal epithelium, without promoting erosion of the maternal tissue (Bazer 1975, Gray et al. 2001). The glandular epithelium is believed to secrete the majority of histotroph to nourish and support development of the conceptus (Spencer et al. 2004). The luminal epithelium of the pig uterus is responsible for endometrial remodeling for non-invasive implantation as well as expresses specific factors that prevent invasion of porcine embryo (Wollenhaupt et al. 2011). Hence, the integrity of both the maternal and fetal tissues is not disrupted by the blood vessels that develop from the blastocyst and those from the uterus (Carson et al. 2000).

We previously described that AQP1, 5 and 9 protein expression in the porcine uterus is influenced by the estrous cycle and pregnancy (Skowronski 2010). In the present study, $\mathrm{E}_{2}$ treatment resulted in a rapid (by $3 \mathrm{~h}$ ) decrease in $A Q P 1$ and $A Q P 5$ gene expression, although longer $(24 \mathrm{~h})$ treatment elevated AQP5 and AQP1 gene expression but only to the control level. Similarly, $\mathrm{P}_{4}$ did not change $A Q P 1$ or $A Q P 5$ mRNA expression at the time of the study. However, the content of AQP1 and 5 proteins was up-regulated in the presence of steroid hormones after 3 and $24 \mathrm{~h}$ exposure. These results indicate that despite low $A Q P 1$ and 5 mRNA transcript abundance, AQP1 and 5 proteins was stable expressed in uterine explants displaying a low turnover rate. 


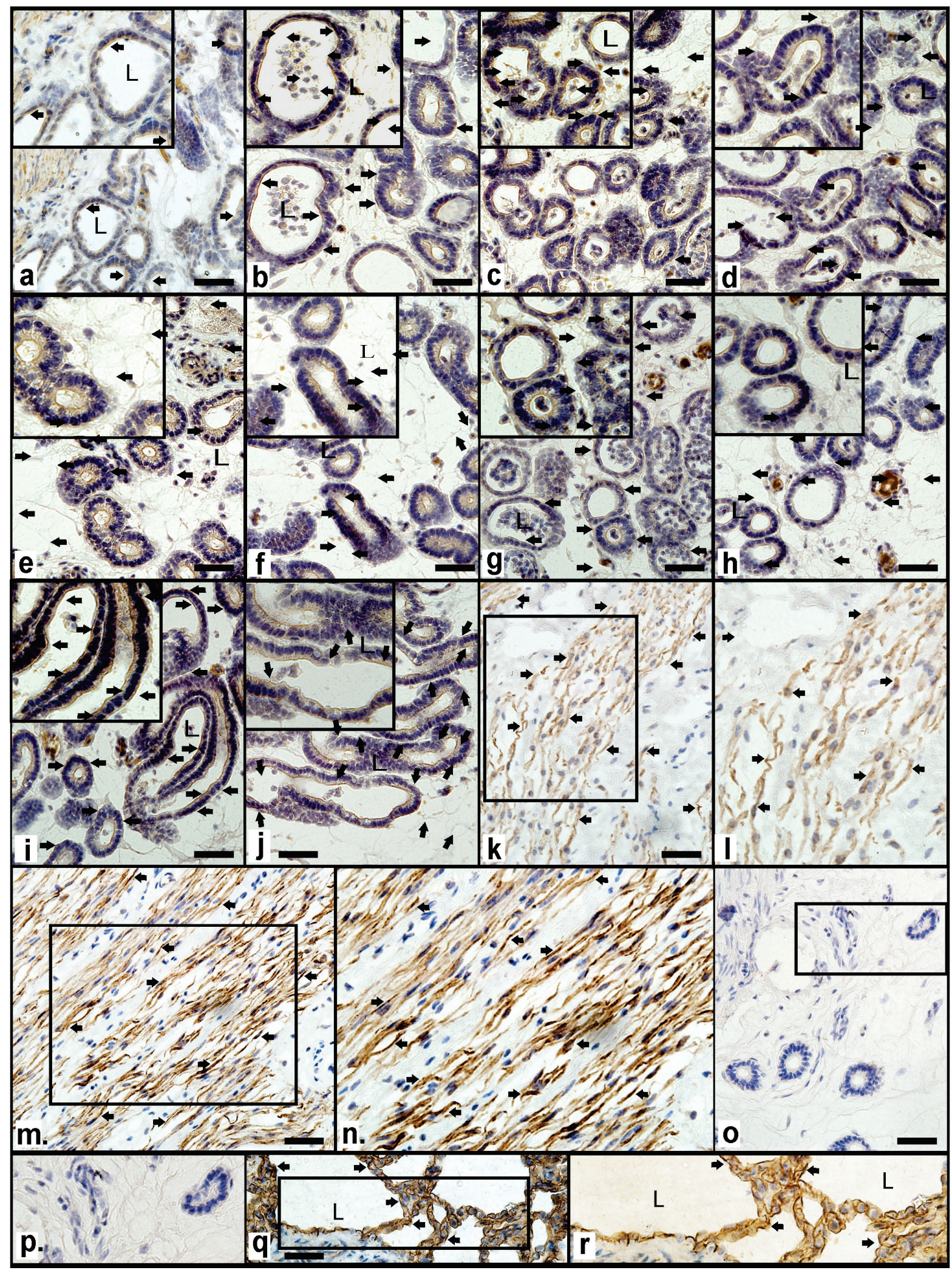

Fig. 6. Immunohistochemical localization of AQP5 in uterine tissue explants. Immunoperoxidase staining of AQP5 in paraffin-embedded sections of the uterine explants from pigs on Days 14-16 of pregnancy. AQP5 antibody stains epithelial cells of the uterine explants (arrows). The labeling is seen only in the apical plasma membranes of the epithelial cells in control on Days 14-16 of pregnancy (a). Continuously, 3-h and 24-h treatments on Days 14-16 of pregnancy of the tissue explants with $P_{4}(\mathbf{b}$ and $\mathbf{c}), E_{2}(\mathbf{d}$ and $\mathbf{e})$, FSK (f and $\mathbf{g}$ ) and CAMP (h and $\mathbf{i})$, respectively, and 3-h with AA (j) prominent AQP5 labeling is seen in both the apical and basolateral plasma membranes of the epithelial cells. AQP5 antibody also stains smooth muscle cells in control (k and $\mathrm{I})$ and $\mathrm{P}_{4}$-treated uterine explants for 3-h ( $\mathbf{m}$ and $\mathbf{n}$ ). No staining was observed with using non-immune immunoglobulins (o and $\mathbf{p} / \mathbf{n e g a t i v e ~ c o n t r o l ) . ~ T h e ~ a n t i - A Q P 5 ~ l a b e l s ~}$ apical membrane of type I pulmonary epithelial cells of the pig ( $\mathbf{q}$ and $\mathbf{r} /$ positive control). $\mathrm{L}-$ lumen. Bar $=50 \mu \mathrm{m}$ 
In general, our results are consistent with other authors and elucidated that $\mathrm{E}_{2}$ and $\mathrm{P}_{4}$ are important regulators of AQP1 and 5 expression in the porcine uterus and have an important role in the implantation process. Taking into account our immunohistochemistry data, we suggest that the finding of AQP5 in glandular epithelial cells in control explants and the presence of AQP5 in both the apical and basolateral plasma membranes of glandular epithelium in uterine explants in response to $\mathrm{P}_{4}$ and $\mathrm{E}_{2}$, strongly corroborates the hypothesis of a transcellular route for the movement of water across in the cells. Furthermore, since AQP5 is hormonally translocated to the basolateral plasma membranes of glandular epithelium, this may provide a functional mechanism for both absorption across the glandular epithelium and reabsorption of glandular contents. Hence, our finding may reveal the importance of steroid hormone regulation of AQP5. Very recently, Zhang et al. (2015) demonstrated upon $\mathrm{E}_{2}$ treatment that AQP5 knockout mice showed significantly decreased luminal fluid volume and number of implantation sites compare with wild-type mice, suggesting that $\mathrm{AQP5}$ are responsible for $\mathrm{E}_{2}$-induced abnormal fluid accumulation. In turn, Zou et al. (2011) demonstrated that $\mathrm{E}_{2}$ may regulate AQP2 expression via an estrogen-response element (ERE) in the AQP2 promoter. One of the prominent effects of estrogen is water imbibition and for the regulation of water transportation, AQP5 play a critical role (Kobayashi et al. 2006). Lindsay and Murphy (2006) showed that up-regulation of AQP1 and AQP5 in the rat uterus was dependent on progesterone alone or in combination with estrogen. Furthermore, in the mouse uterus exogenous estrogen strongly up-regulated the expression of AQP2, without any effect on AQP5 (Jablonski et al. 2003).

Our findings agreed with several previous observations in other species by $\mathrm{Li}$ et al. (1997) and Kobayashi et al. (2006) who studied this steroid action on uterine expression of AQP1 in rats and AQP5 in mice, respectively. Our data differ partially from the results obtained by Richard et al. (2003), who found increased $A Q P 1$ mRNA in mice myometrium in response to estrogen, but did not evaluate the expression of AQP1 at the protein level, and AQP5 expression was induced by estrogen only in progesterone-primed animals. Thus, it seems that steroid hormones may regulate AQPs gene expression both in a positive and negative regulative manner, depending on the physiological status of animal and tissue types and function. As observed in the present study, the lack of a full relationship between the concentration of gene transcripts and respective proteins may also result from: 1. differentiated stability of mRNAs or proteins, as well as the regulation of transcription, post-transcriptional processes or translation, 2. functional feedback, i.e. a high protein product may suppress gene transcript into mRNA, and a higher mRNA level may diminish the post-transcriptional process. Here, we can hypothesize that regulation of AQPs expression seemed to occur at the post-transcriptional level as protein expression upon Western-blot was pronounced. Further, those inverse relations are not accidental, they also happened in other studies performed by Klein et al. (2013) and Ducza et al. (2014). Therefore, it is not clear how tightly transcription and translation are correlated during such development processes. One limitation of the analysis of uterine explants is the complex and dynamics tissue composition. There are luminal and glandular epithelial cells, stromal cells, endothelial cells and various immune cells. Implantation and embryo development are the critical moments in reproduction, it is a complex process involving numerous genes (regulating uterine receptivity and blastocyst implantation), mRNAs, proteins in the endometrium and synchronism of maternal uterus and embryo and the intricate maternal-fetal dialogue (Liu et al. 2014). Pregnant gilts were used in our experiment and their endometrium would have already been exposed to the embryo signal and resulted in altered expression of target genes of interest.

The present experiments showed that OT increased $A Q P 1$ mRNA expression after 24-h and decreased $A Q P 5$ mRNA after 3 and $24 \mathrm{~h}$ incubation, but had no effect on AQP1 or AQP5 protein content. These results partially are in agreement with the data obtained very recently by Ducza et al. (2014). They indicated that OT treatment increased $A Q P 2$ mRNA levels but also specifically reduced the expression of $A Q P 5$ in the rat uterus on Day 18 of pregnancy. In our recent published paper, oxytocin has been shown to decreased $A Q P 1 / 5$ mRNA expression, without visible changes in protein content in vitro (Skowronska et al. 2015). However, our unpublished data (Skowronska et al. unpublished) revealed that the myometrial slices are responsive to OT leading to an increase in both $\mathrm{AQP}$ isoforms. The changes in AQPs expression were more pronounced in myometrial slices compare to endometrial slices. We speculate that the endometrial/myometrial responsiveness to oxytocin increases because of the changes in the steroid environment, and perhaps due to an inhibitory 
action of OT on AQPs uterine expression is abolished after separation of the uterine endometrium and myometrium.

The present study results showed that AQP1 and AQP5 mRNA and protein were regulated by arachidonic acid in the porcine uterus during implantation. Prostaglandin $\mathrm{E}_{2}\left(\mathrm{PGE}_{2}\right)$ is the major cyclooxygenase product of arachidonate metabolism in the porcine uterus (Hertelendy and Zakar 2004). Arachidonic acid decreased $A Q P 1$ mRNA expression after 3-h incubation, while longer $(24 \mathrm{~h})$ exposure to AA increased both $A Q P 1$ mRNA and protein expression. Although the $A Q P 5$ mRNA expression was down-regulated after a 3-h AA treatment, the AQP5 protein concentration increased, so an inverse relation was found between expression both in gene and protein levels. These results indirectly indicate that AA-prostaglandins (PG) are involved in the regulation of $\mathrm{AQP} 1$ and $\mathrm{AQP5}$ protein expression in uterine tissue during implantation, because elevated AQP1 and 5 protein concentrations in the porcine uterus. Additionally, immunohistochemistry results confirmed the changes in cellular localization of AQP5 in response to AA. After 3-h treatment with AA, prominent AQP5 labeling was seen in both the apical and basolateral plasma membranes of the glandular epithelial cells. Previously, other research groups (Geisert et al. 1986) demonstrated that pharmacological inhibition of $P G$ synthesis does not affect trophoblast elongation in pigs. However, inhibition of PG synthesis during the period of trophoblast attachment (Days 13 to 18) results in embryonic mortality (Kraeling et al. 1985). Prostaglandins produced by the uterus play an essential role in regulation of the estrous cycle and during maternal recognition of pregnancy in many species, including the pig (Kennedy et al. 2007) and are involved in implantation, control of cytokine release, cell growth and differentiation and vascular responses (Kelly et al. 2001, Bazer et al. 2010). Based on those literature reports and the present results, we propose that $\mathrm{AA}$ is a regulator of AQP 1 and 5 expression at the time of implantation because it may regulate both AQP1 and AQP5 gene and protein content in the porcine uterus. In line with those reports, we suggest that $\mathrm{AQP} 1$ and 5 amplified by $\mathrm{AA}$ may play an important role in balancing uterine fluid, stromal edema and embryo-maternal communication. There is limited data describing the effect of PGs on AQPs expression. The effect of $\mathrm{PGE}_{2}$ on the actions of arginine vasopressin (AVP) and AQP2 phosphorylation and distribution was examined in the rat renal medulla, and it was found that $\mathrm{PGE}_{2}$ stimulated the retrieval of AQP2 from the plasma membrane in AVP-stimulated tissue (Zelenina et al. 2000).

The present study showed that FSK and cAMP differ in the regulation of the expression of AQP1 and AQP5 gene and protein. FSK and cAMP increased AQP1 mRNA and protein expression after $24 \mathrm{~h}$ of incubation but had no effect after $3 \mathrm{~h}$. However, FSK had no effect on AQP5 mRNA expression after 3 and $24 \mathrm{~h}$, but increased AQP5 protein concentration. Furthermore, cAMP up-regulated AQP5 mRNA expression after 24-h incubation but, as well as FSK, increased AQP5 protein concentration after 3 and $24 \mathrm{~h}$. These results showed that the stimulatory effect of FSK and cAMP on AQP1, but not AQP5 protein expression could depend on the incubation period. The above results strongly suggest that expression of both AQPs are regulated by cAMP and FSK but specially the AQP5, because AQP5 protein content was elevated after 3 as well as $24 \mathrm{~h}$ in the porcine uterine explants during implantation. These results are generally consistent with the data obtained previously with the use of different cells/tissues (Wang et al. 2006, 2007, Yang et al. 2003) or cell lines (Wang et al. 2003, Belkacemi et al. 2008).

In this study, we revealed by immunohistochemistry the changes in cellular localization of AQP5 in response to the studied factors in the uterine tissue explants (Fig. 6). AQP1 localization was mainly associated with the apical and basal membranes of the uterine endothelium cell, but AQP5 was mainly associated, in the control explants, with the apical membranes of epithelial cells, the secretion side of the uterine glandular epithelium, It is noteworthy that $\mathrm{P}_{4}, \mathrm{E}_{2}$, AA, FSK and cAMP caused an emergence of AQP5 in the basolateral membrane of the epithelial cells. It might be hypothesized that these changes are connected with potentially bidirectional transcellular water movement through uterine epithelial cells at the time of implantation in the pig. The changes in cellular localization of AQPs in the uterus during the implantation period have been already observed in rodents (Richard et al. 2003, Lindsay and Murphy 2004, 2006, 2007). These results suggest that specific AQPs localization provides a mechanism for transcellular fluid transport. Furthermore, Garcia et al. (2001) indicated that cAMP may induce translocation and insertion of AQP8 within intracellular vesicular structures to plasma membranes in the rat hepatocytes. Our recent studies (Skowronska et al. 2015) performed on the uterine explants from cyclic gilts demonstrated that 
steroid hormones, AA, FSK and cAMP cause translocation of AQP5 from the apical to basolateral plasma membrane of the glandular epithelial cells.

With reference to our recent published research (Skowronska et al. 2015), the uterine explants from non-pregnant pigs collected on Days 14-16 of the cycle differed from those collected on Days 14-16 of pregnancy. The pregnant gilts (present data) expressed 4.5-fold higher abundance of $A Q P 1$ mRNA compared to the corresponding stage of the estrous cycle (Days 14-16). Whereas, cyclic gilts expressed 3-fold higher abundance of AQP5 mRNA than the pregnant gilts. Moreover, an inverse relationship was found in regulation of $A Q P 1$ and $A Q P 5$ gene expression during the luteolysis and early pregnancy. The third difference observed between the pregnant and cyclic uterine explants was in the protein expression, responses of AQP1 to $\mathrm{P}_{4}, \mathrm{E}_{2}, \mathrm{AA}$, FSK and cAMP treatment after short incubation appeared to be higher during luteolysis versus implantation. These results indicate that the presence of conceptus may influence $A Q P s$ expression in the uterine explants.

In conclusion, the present study is the first in vitro demonstration that $\mathrm{P}_{4}, \mathrm{E}_{2}, \mathrm{AA}, \mathrm{FSK}$ and cAMP up-regulated AQP1 and AQP5 expression in the porcine uterus during implantation period. The changes in AOPs expression appeared to be dependent on duration of the tissue exposure to experimental factors. Moreover, treatment with $\mathrm{P}_{4}, \mathrm{E}_{2}, \mathrm{AA}, \mathrm{FSK}$ and cAMP caused the expression of AQP5 also in the basolateral plasma membrane of the epithelial cells, suggesting transcellular (through the epithelial cells) water movement between the uterine lumen and blood vessels. Overall, these results indicate the important role of AQP1 and AQP5 in keeping local fluid balance within the pig uterus and embryo-maternal communication during implantation.

\section{Conflict of Interest}

There is no conflict of interest.

\section{Acknowledgements}

This work was supported by Grant Number N N308 5848 40 awarded to MTS from the Polish Ministry of Science and Higher Education.

\section{References}

AGRE P, KING L, YASUI M, GUGGINO WB, FUJIYOSHI Y, ENGEL A, NIELSEN S: Aquaporin water channels from atomic structure to clinical medicine. $J$ Physiol 542: 3-16, 2002.

AKINLOSOTU BA, DIEHL JR, GIMENEZ T: Sparing effects of intrauterine treatment with prostaglandin E2 on luteal function in cycling pigs. Prostaglandins 32: 291-299, 1986.

BAZER FW: Uterine protein secretions: relationship to development of the conceptus. J Anim Sci 41: 1376-1382, 1975.

BAZER FW, SPENCER TE, JOHNSON GA, BURGHARDT RC, WU G: Comparative aspects of implantation. Reproduction 138: 195-209, 2009.

BAZER FW, WU G, SPENCER TE, JOHNSON GA, BURGHARDT RC, BAYLESS K: Novel pathways for implantation and establishment and maintenance of pregnancy in mammals. Mol Hum Reprod 16: 135-152, 2010.

BELKACEMI L, BEALL MH, MAGEE TR, POURTEMOUR M, ROSS MG: AQP1 gene expression is upregulated by arginine vasopressin and cyclic AMP agonist in trophoblast cells. Life Sci 82: 1272-1280, 2008.

CARSON DD, BAGCHI I, DEY SK, ENDERS AC, FAZLEABAS AT, LESSEY BA, YOSHINAGA K: Embryo implantation. Dev Biol 223: 217-237, 2000.

CHRISTENSON LK, FARLEY DB, ANDERSON LH, FORD SP: Luteal maintenance during early pregnancy in the pig role for prostaglandin E2. Prostaglandins 47: 61-75, 1994.

DUCZA E, SERES AB, HAJAGOS-TOTH J, FALKAY G, GASPAR R: Oxytocin regulates the expression of aquaporin 5 in the late-pregnant rat uterus. Mol Reprod Dev 81: 524-530, 2014.

ESCOBAR J, GORMAZ M, ARDUINI A, GOSENS K, MARTINEZ A, PERALES A, ESCRIG R, TORMOS E, ROSELLO M, ORELLANA C, VENTO M: Expression of aquaporins early in human pregnancy. Early Hum Dev 88: 589-594, 2012.

FRANCZAK A, KOTWICA G, KUROWICKA B, OPONOWICZ A, WACŁAWEK-POTOCKA J, PETROFF BK: Expression of enzymes of cyclooxygenase pathway and secretion of prostaglandin E2 and F2 $\alpha$ by porcine myometrium during luteolysis and early pregnancy. Theriogenology 66: 1049-1056, 2006. 
GARCIA F, KIERBEL A, LAROCCA MC, GRADILONE SA, SPLINTER P, LARUSSO NF, MARINELLI RA: The water channel aquaporin- 8 is mainly intracellular in rat hepatocytes and its plasma membrane insertion is stimulated by cyclic AMP. J Biol Chem 276: 12147-12152, 2001.

GEISERT RD, RASBY RJ, MINTON JE, WETTEMANN RP: Role of prostaglandins in development of porcine blastocyst. Prostaglandins 31: 191-204, 1986.

GEISERT R, FAZLEABAS A, LUCY M, MATHEW D: Interaction of conceptus and endometrium to establish pregnancy in mammals: role of interleukin 1ß. Cell Tissue Res 349: 825-838, 2012.

GRAY CA, BARTOL FF, TARLETON BJ, WILEY AA, JOHNSON GA, BAZER FW, SPENCER TE: Developmental biology of uterine glands. Biol Reprod 65: 1311-1323, 2001.

HERTELENDY F, ZAKAR T: Prostaglandins and the myometrium and cervix. Prostaglandins Leukot Essent Fatty Acids 70: 207-222, 2004.

HUA Y, JIANG W, ZHANG W, SHEN Q, CHEN M, ZHU X: Expression and significance of aquaporins during pregnancy. Front Biosci 18: 1373-1383, 2013.

HUANG HF, HE RH, SUN CC, ZHANG Y, MENG QX, MA YY: Function of aquaporins in female and male reproductive systems. Hum Reprod Update 12: 785-795, 2006.

JABLONSKI EM, MCCONNELL NA, HUGHES FM Jr, HUET-HUDSON YM: Estrogen regulation of aquaporins in the mouse uterus: potential roles in uterine water movement. Biol Reprod 69: 1481-1487, 2003.

JAEGER LA, JOHNSON GA, KA H, GARLOW JG, BURGHARDT RC, SPENCER TE, BAZER FW: Functional analysis of autocrine and paracrine signalling at the uterine-conceptus interface in pigs. Reprod Suppl 58: 191-207, 2001.

JOHNSON GA, BAZER FW, BURGHARDT RC, SPENCER TE, WU G, BAYLESS KJ: Conceptus-uterus interactions in pigs: endometrial gene expression in response to estrogens and interferons from conceptuses. Soc Reprod Fertil Suppl 66: 321-332, 2009.

KAUFMANN P, BURTON G: Anatomy and genesis of the placenta. In: The Physiology of Reproduction. JD KNOBIL, NY NEILL (eds), Elsevier, St. Louis, MO, USA, 441-484, 1999.

KELLY RW, KING AE, CRITCHLEY HO: Cytokine control in human endometrium. Reproduction 121: 3-19, 2001.

KENNEDY TG, GILLIO-MEINA C, PHANG SH: Prostaglandins and the initiation of blastocyst implantation and decidualization. Reproduction 134: 635-643, 2007.

KEYS JL, KING GJ: Microscopic examination of porcine conceptus-maternal interface between days 10 and 19 of pregnancy. Am J Anat 188: 221-238, 1990.

KLEIN C, TROEDSSON MHT, RUTLLANT J: Expression of aquaporin water channels in equine endometrium is differentialy regulated during the oestrus cycle and early pregnancy. Reprod Dom Anim 48: 529-537, 2013.

KOBAYASHI M, YASUI M: Cellular and subcellular localization of aquaporins 1, 3, 8 and 9 in amniotic membranes during pregnancy in mice. Cell Tissue Res 342: 307-316, 2010.

KOBAYASHI M, TAKAHASHI E, MIYAGAWA S, WATANABE H, IGUCHI T: Chromatin immunoprecipitationmediated target identification proved aquaporin 5 is regulated directly by estrogen in the uterus. Genes Cells 11: 1133-1143, 2006.

KRAELING RR, RAMPACEK GB, FIORELLO NA: Inhibition of pregnancy with indomethacin in mature gilts and prepuberal gilts induced to ovulate. Biol Reprod 32: 105-110, 1985.

LI XJ, YU HM, KOIDE SS: Regulation of water channel gene (AQP-CHIP) expression by estradiol and anordiol in rat uterus. Yao Xue Xue Bao 32: 586-592, 1997.

LINDSAY LA, MURPHY CR: Redistribution of aquaporins in uterine epithelial cells at the time of implantation in the rat. Acta Histochem 106: 299-307, 2004.

LINDSAY LA, MURPHY CR: Redistribution of aquaporins 1 and 5 in the rat uterus is dependent on progesterone: a study with light and electron microscopy. Reproduction 131: 369-378, 2006.

LINDSAY LA, MURPHY C: Aquaporins are up-regulated in glandular epithelium at the time of implantation in the rat. J Mol Hist 38: 87-95, 2007.

LIU XM, ZHANG D, WANG TT, SHENG JZ, HUANG HF: Ion/water channels for embryo implantation barrier. Physiology 29: 186-195, 2014. 
NIELSEN S, KING LS, CHRISTENSEN BM, AGRE P: Aquaporins in complex tissues. II. Subcellular distribution in respiratory and glandular tissues of rat. Am J Physiol 273: C1549-C1561, 1997.

RICHARD C, GAO JU, BROWN N, REESE J: Aquaporin water channel genes are differentially expressed and regulated by ovarian steroids during the periimplantation period in the mouse. Endocrinology 144: 1533-1541, 2003.

SHA XY, XIONG ZF, LIU HS, DI XD, MA TH: Maternal-fetal fluid balance and aquaporins: from molecule to physiology. Acta Pharmacol Sin 32: 716-720, 2011.

SKOWRONSKA A, MLOTKOWSKA P, WOJCIECHOWICZ B, OKRASA S, NIELSEN S, SKOWRONSKI MT: Progesterone, estradiol, arachidonic acid, oxytocin, forskolin and cAMP influence on aquaporins 1 and 5 expression in porcine uterine explants during the mid-luteal phase of the estrous cycle and luteolysis: an in vitro study. Reprod Biol Endocrinol 13: 7, 2015.

SKOWRONSKI MT: Distribution and quantitative changes in amounts of aquaporin 1, 5 and 9 in the pig uterus during the estrous cycle and early pregnancy. Reprod Biol Endocrinol 8: 109, 2010.

SKOWRONSKI MT, LEBECK J, ROJEK A, PRAETORIUS J, FUCHTBAUER EM, FRØKIÆR J, NIELSEN S: AQP7 is localized in capillaries of adipose tissue, cardiac and striated muscle: implications in glycerol metabolism. Am J Physiol Renal Physiol 292: F956-F965, 2007.

SKOWRONSKI MT, KWON TH, NIELSEN S: Immunolocalization of aquaporin 1, 5, and 9 in the female pig reproductive system. $J$ Histochem Cytochem 57: 61-67, 2009.

SPENCER TE, JOHNSON GA, BAZER FW, BURGHARDT RC: Implantation mechanisms: insights from the sheep. Reproduction 128: 657-668, 2004.

TERRIS J, ECELBARGER CA, NIELSEN S, KNEPPER MA: Long-term regulation of four renal aquaporins in rats. Am J Physiol 271: F414-F422, 1996.

TROUT WE, SMITH GW, GENTRY PC, GALVIN JM, KEISLER DH: Oxytocin secretion by the endometrium of the pig during maternal recognition of pregnancy. Biol Reprod 52 (Suppl 1): 189, 1995.

UZUMCU M, BRAILEANU GT, CARNAHAN KG, LUDWIG TE, MIRANDO MA: Oxytocin-stimulated phosphoinositide hydrolysis and prostaglandin $\mathrm{F}$ secretion by luminal epithelial, glandular epithelial and stromal cells from pig endometrium. I. Response of cyclic pigs on day 16 postestrus. Biol Reprod 59: 1259$1265,1998$.

WANG S, CHEN J, AU KT, ROSS MG: Expression of aquaporin 8 and its up-regulation by cyclic adenosine monophosphate in human WISH cells. Am J Obstet Gynecol 188: 997-1001, 2003.

WANG S, AMIDI F, BEALL M, GUI L, ROSS MG: Aquaporin 3 expression in human fetal membranes and its up-regulation by cyclic adenosine monophosphate in amnion epithelial cell culture. J Soc Gynecol Investig 13: 181-185, 2006.

WANG S, AMIDI F, YIN S, BEALL M, ROSS MG: Cyclic adenosine monophosphate regulation of aquaporin gene expression in human amnion epithelia. Reprod Sci 14: 234-240, 2007.

WHITEAKER SS, MIRANDO MA, BECKER WC, HOSTETLER CE: Detection of functional oxytocin receptors on endometrium of pigs. Biol Reprod 51: 92-98, 1994.

WOLLENHAUPT K, REINKE K, BRUSSOW KP, SPITSCHAK M, KANITZ W, TOMEK W: Truncation of the mRNA cap-binding protein eIF4E is specific for the non-invasive implantation in pigs. Reprod Dom Anim 46: 917-919, 2011.

XIONG Y, TAN YJ, XIONG YM, HUANG YT, HU XL, LU YC, YE YH, WANG TT, ZHANG D, JIN F, HUANG HF, SHENG JZ: Expression of aquaporins in human embryos and potential role of AQP3 and AQP7 in preimplantation mouse embryo development. Cell Physiol Biochem 31: 649-658, 2013.

YANG F, KAWEDIA JD, MENON AG: Cyclic AMP regulates aquaporin 5 expression at both transcriptional and posttranscriptional levels through a protein kinase A pathway. J Biol Chem 278: 32173-32180, 2003.

ZELENINA M, CHRISTENSEN BM, PALMER J, NAIRN AC, NIELSEN S, APERIA A: Prostaglandin E2 interaction with AVP: effects on AQP2 phosphorylation and distribution. Am J Physiol Renal Physiol 278: F388-F394, 2000.

ZHANG D, TAN YJ, QU F, SHENG JZ, HUANG HF: Functions of water channels in male and female reproductive systems. Mol Aspects Med 33: 676-690, 2012. 
ZHANG Y, CHEN Q, ZHANG H, WANG Q, LI R, JIN Y, WANG H, MA T, QIAO J, DUAN E: Aquaporin-dependent excessive intrauterine fluid accumulation is a major contributor in hyper-estrogen induced aberrant embryo implantation. Cell Res 25: 139-142, 2015.

ZHU C, JIANG Z, BAZER FW, JOHNSON GA, BURGHARDT RC, WU G: Aquaporins in the female reproductive system of mammals. Front Biosci 20: 838-871, 2015.

ZIECIK AJ, WACLAWIK A, KACZMAREK MM, BLITEK A, JALALI BM, ANDRONOWSKA A: Mechanisms for the establishment of pregnancy in the pig. Reprod Domest Anim 46 (Suppl 3): 31-41, 2011.

ZOU LB, ZHANG RJ, TAN YJ, DING GL, SHI S, ZHANG D, HE RH, LIU AX, WANG TT, LEUNG PCK, SHENG JZ, HUANG HF: Identification of estrogen response element in the aquaporin-2 gene that mediates estrogeninduced cell migration and invasion in human endometrial carcinoma. J Clin Endocrinol Metab 96: E1399E1408, 2011. 